\title{
İnternette ya da Çevrimiçi Pazarlamada Yeni Bir Kavram: Bağlı Kuruluş (Satış Ortaklığı) Pazarlaması ve Türkiye Pazarından Bazı Örnekler
}

DOI: 10.26466/opus. 913655

\author{
Evrim İldem Develi* \\ *Dr. Öğr. Üyesi, İstanbul Ticaret Üniversitesi, İstanbul/Türkiye \\ E-Posta: evrimildem@gmail.com \\ ORCID: $0000-0003-3842-8611$
}

\begin{abstract}
Öz
Teknolojide yaşanan yenilikler ve bunların insan hayatı üzerindeki etkileriyle birlikte, teknolojinin yerinin daha fazla hayatlarda varlık göstermesi sonucunda internette pazarlama ya da bir diğgr ifadeyle çevrimiçi pazarlama, dijital pazarlama gibi teknoloji ve internet tabanl pazarlama faaliyetleri literatüre ve insan hayatına girmiş oldu. Bu gelişmelerden hareketle işletmeler ürün veya hizmetlerini ilgili hedef kitleleriyle buluşturabilmek, marka tanınırlı̆̆ın, bilinirliğini ve görünürlüğ̈̈̈nü arttırmak, ürün satışını yükseltmek amacıyla çevrimiçi platformlar üzerinden oluşturulan medya stratejilerine ağırlık vermeye başladı. Bu bağlamda performansa dayal pazarlama stratejileri kapsamında ortaya çıkan kavramlardan biri olan ve "influencer marketing" yani "etkileyici pazarlaması" kavramin da kapsayan "affiliate marketing" Türkçe adıyla "bağ̆l kuruluş ya da satış ortaklığı pazarlaması" stratejisi daha çok kullanılmaya başlandı. Çalışmanın ilk bölümünde bağlı kuruluş ya da satış ortaklığı pazarlaması stratejisi üzerinde durularak kavramın tarafları, sistemin özellikleri, reklamveren işletmelere sunduğu faydalar ve zorluklar ile sistemin teknik olarak işleyişi hakkında bilgi verilmiştir. Çalışmada literatürde bağ̆l kuruluş ya da satış ortaklığı pazarlaması alanında yapılmış çalışmaların derlenmesi yoluyla ikincil araştırma yöntemi kullanılmıştır. Ayn zamanda Türkiye pazarında faaliyet gösteren ve bazı internet kaynaklarınca güvenilir olarak ifade edilen bağlı kuruluşörneklerine yer verilmiştir.
\end{abstract}

Anahtar Kelimeler: Çevrimiçi Pazarlama, Performansa Dayalı Pazarlama, Bağhı Kuruluş Ya Da Satış Ortaklı̆̆ı Pazarlaması. 


\title{
New Concept in Online Marketing: Affiliate Marketing and Some Examples from Turkish Market
}

\begin{abstract}
Developments and innovations in technology resulted as the presence of technology more in lives. Technology and internet-based marketing activities such as online marketing or digital marketing have entered literature and human life. Based on these developments, businesses started to focus on media strategies created on online platforms in order to show their products or services to their target audience, to increase brand recognition, awareness and visibility and also to increase product sales. In this context, "affiliate marketing", which is one of the concepts that emerged within the scope of performance-based marketing strategies, started to be used more often. In first part of the study, the marketing strategy through affiliate marketing was emphasized, the parties were introduced and information was given about technical functioning and the features of the system, and also the benefits and difficulties it offers to the parties of the system. As a method, secondary research method was used by compiling the studies in the field of marketing through affiliate marketing. Also, as a reference of some of the internet market place some reliable affiliate sources operating in Turkey are placed as affiliates example.
\end{abstract}

Keywords: $\quad$ Online Marketing, Performance Based Marketing, Affiliate Marketing. 


\section{Giriş}

Teknolojide yaşanan gelişmeler ve bunların insan hayatı üzerindeki etkileriyle birlikte, teknolojinin daha fazla hayatlarda varlık göstermesi sonucunda internette pazarlama ya da bir diğer ifadeyle çevrimiçi pazarlama, dijital pazarlama gibi teknoloji ve internet tabanlı pazarlama faaliyetleri literatüre ve insan hayatına girmiş oldu. Bu gelişmelerden hareketle işletmeler ürün veya hizmetlerini ilgili hedef kitleleriyle buluşturabilmek, marka tanınırlı̆̆ını, bilinirliğini ve görünürlügünü arttırmak, ürün satışını yükseltmek amacıyla çevrimiçi platformlar üzerinden oluşturulan medya stratejilerine ağırlık vermeye başladı.

$\mathrm{Bu}$ kavramla beraber internet, tüketicilerin ve müşterilerin ihtiyaçlarını karşılayacak ürün ve hizmetlere erişimleri açısından önemli bir tutundurma aracı haline gelmiştir (Gedik, 2020a, s.63). Bu bağlamda performansa dayalı pazarlama stratejileri kapsamında ortaya çıkan kavramlardan biri olan "affiliate marketing" Türkçe adıyla "bağlı kuruluş ya da satış ortaklığı pazarlaması" stratejisi daha çok kullanılmaya başladı.

İnternet üzerinden pazarlama faaliyetlerinin yürütülmesiyle birçok iş modeli ortaya çıkmış, aynı zamanda klasik yöntemlerde uygulanan çeşitli modeller de dijital platforma taşınmıştır. Bu bağlamda, internette pazarlama ya da çevrimiçi pazarlama kavramı arasında bulunan bir iş modeli olan bağlı kuruluş bir diğer ismiyle satış ortaklığ 1 iş modeli bu çalışmanın konusunu oluşturmaktadır.

Çalışmada ilk olarak internette pazarlama kavramına yer verilmektedir. İnternette pazarlama kavramlarından olan bağlı kuruluş ya da satış ortaklığ 1 kavramı çalışmanın odak konusunu oluşturmakta olup bu kavramın yerli ve yabancı literatürdeki yeri literatür taraması biçiminde çalışmada yer almaktadır.

\section{İnternette (Çevrimiçi) Pazarlamada Bağlı Kuruluş (Satış Ortaklığı) Pazarlamasına İlişkin Literatür Taraması}

İnternette pazarlama diğer adıyla çevrimiçi pazarlama internet ve internet teknolojilerinin kullanımıyla birlikte ortaya çıkmış bir pazarlama türüdür. İnternette pazarlama stratejileri ürün, fiyat dağıtım ve tutundurma şeklinde ifade edilmektedir. Bu çalışma çerçevesinde internette 
pazarlama karması unsurlarından olan tutundurma karmasının alt bileşeninde yer alan internet reklamcılığı ya da çevrimiçi (online) reklamcılığın bir türü; performansa dayalı bir sistem olan bağlı kuruluş (satış ortaklığı) pazarlaması ele alınacaktır.

Kotler ve Keller'e göre (2009, s.158) pazarlama iletişimi işletmelerin ya da toplulukların tüketicileri sattıkları ürün, marka ya da hizmetler hakkında doğrudan ya da dolaylı olarak bilgilendirdikleri, ikna ettikleri ve hatırlattıkları bir ortam olarak ifade edilmektedir.

Fill'e (2013, s.54-57) göre, teknolojik ilerlemenin etkisi olarak hızlı etkileşim ve iki yönlü iletişim, iletişim stratejileri ve hedef kitle ile nasıl iletişim kurulacağına dair yeni bir anlayış gerektirmektedir. Doğrudan etkileşim yeteneği, dijital medyanın sunduğu temel özelliktir ve onu geleneksel medyadan farklı kılmaktadır.

Çevrimiçi reklamcılık, müşterileri çekmek amacıyla pazarlama mesajları iletmek için internet ile birlikte internet ortamını kullanan bir tanıtım biçimidir. İnternette bir şirketin internet (web) sitesine sahip olmak artık çevrimiçi reklamcılık olarak görülmede yeterli gelmemektedir. Bunun yerine reklam, müşterileri o internet sitesine çekmenin yolunu oluşturur (Hossan ve Ahammad, 2013, s.106).

İnternet ortamlarının gelişmesiyle beraber çevrimiçi reklamcılık alanlarında çeşitli kavramlar ortaya çıkmıştır. Bu kavramlardan biri olan bağlı kuruluş (satış ortaklığı) pazarlaması diğer internet pazarlama yöntemleriyle bir noktaya kadar benzeşir. Bunun sebebi bağlı kuruluşların genellikle organik arama motoru optimizasyonu (SEO), ücretli arama motoru pazarlaması (PPC - Tıklama Başına Ödeme), içerik pazarlaması ve bir anlamda görüntülü reklamcllı gibi normal internet reklam yöntemlerini kullanmalarıdır. Diğer taraftan, bağlı kuruluşlar bir ortak tarafından sunulan ürün ya da hizmetlerin araştırmalarını yayınlamak gibi daha az geleneksel yöntemlere yönelir (Nosrati vd., 2013, s.59).

\section{Bağlı Kuruluş (Satış Ortaklığı) Pazarlaması}

İngilizce adı "affiliate marketing" olan ve Türkçe'de bağlı kuruluş ya da satış ortaklığı pazarlaması olarak ifade edilen bu kavram, performansa dayalı pazarlama türü olarak literatürde yer almaktadır. Bir işletmenin ya da bağlı kuruluşun pazarlama çabalarıyla gelen her bir ziyaretçi veya 
müşteri için bir ya da daha fazla bağlı kuruluşu ödüllendirdiği; bir tür performansa dayalı pazarlama olarak tanımlanmaktadır (Pirilancer, https://pirilancer.com/satis-ortakligi-veren-firmalar-yerli-yabanciaffiliate-marketing-siteleri?, 2021)

Performansa dayalı pazarlama, bir işletmenin bir ya da daha çok ortağının o işletmenin ürün ya da hizmetleri için gerçekleştirdiği reklam veya tanıtım etkinlikleri sonucunda, müşterilerin bir hareket gerçekleştirdiği ve bunun karşılığında ortakların ödüllendirilmesi olarak ifade edilmektedir. Eylemin ya da hareketin ne olduğu işletme tarafından önceden tanımlanarak bu sayede işletmenin gerçek ve ölçülebilir sonuçlardan yola çıkarak reklama yönelik harcama yapmasına olanak tanır (Ryan, 2017, s.320).

Bağlı kuruluş (satış ortaklığı) pazarlaması iki işletme arasında gelir paylaşımına dayanan anlaşmalı bir sistem olarak tanımlanmaktadır (Mathur vd., 2018, s.1). Bir işletme diğer bir işletmeye ürün ya da hizmetlerini internet sitesinde tanıtması için parayla ödüllendirir. Müşteriler, bağlı kuruluşun internet sitesini ziyaret ederek buradaki ürün ya da hizmetlere erişirler. Reklamları internet sitesinde barındırdığı için yayınc1ya veya internet sitesine bir bedel ödenecektir (Prabhu ve Satpathy, 2015, s.278). Bu yöntemle, perakendeciye yeni müşteri kazandırılır. Trafiğin bir kısmı bağlı kuruluşların internet sitesine taşınacaktır. Bağlı kuruluş ya da satış ortaklığı modeli az sayıda müşteriye sahip olan ve yeni müşteri elde etmek isteyen işletmeler için uygundur (Gupta ve Aggarwal, 2019, s.476; Norouzi, 2017, s.303).

Bağlı kuruluş (satış ortaklığı) pazarlamasının tarihi, ilk olarak 1989'da kurulan Prodigy ağında PC Flowers \& Gifts olarak bilinmektedir. Kurucusu Tobin, internet bağlı kuruluş pazarlaması fikrini tasarlayarak kendi şirketinin internet sitesinde uyguladı. 1998' de programın 2700'den fazla ortağı bulunmaktaydı (Ryan, 2017, s.320; Wikipedia, 2020).

İkinci olarak, kompakt disk ve müzikle ilgili ürünler satan çevrimiçi alışveriş internet sitesini işleten CD Now şirketinin komisyon programı 1994'e dayanmaktadır. CD Now şirketi, müzik albümlerinin incelemelerini yazmaya, belirli bir albümü satma olasılığına adanmış çeşitli internet sitelerine teklif vererek sistemi yürütmekteydi. Sistem, ziyaretçinin müzik sunucusundaki yorumları okuyabilmesi için çalıştı. İlgilenen ziyaretçileri CD Now'a yönlendirmek için bir köprü görevi oluşturuyordu. Sa- 
tın alma yapılırsa ziyaretçinin incelemeyi okuduğu sunucuya belirli bir komisyon verilirdi. Üçüncü ve en bilinen olarak 1996'da, şu anda dünyanın en büyük ortaklık programlarından biri olan Amazon Ortaklık Programı geliştirildi (Jurišová, 2013, s.107).

$\mathrm{Bu}$ iş modelinde işletme, ürün ya da hizmetini satmak amaciyla pazarda bulunan satış ortakları ile anlaşmaktadır. Bu sayede işletme satış ortaklığı modeli içerisinde yer almaktadır. İş modelinde yer alan işletme bedelsiz olarak ya da belirli bir oranda komisyon bedeli karşıllı̆ında ürün ya da hizmetini satabilmektedir (Öncü, 2014, s.163; Olbrich vd., 2019, s.48).

$\mathrm{Bu}$ sistemde işleyiş 4 taraf üzerine odaklanmaktadır (Mathur, vd., 2018, s.1-2; Öncü, 2014, s.163; Ryan, 2017, s.321-323):

- Tüccar / Reklamveren / Marka: Perakendecinin, markanın yani işletmenin öne çıkan ürünü ya da hizmeti olarak tanımlanır. Sistemde yer alan reklamverenler arasında çoğunlukla perakende markaları, seyahat işletmeleri, finans kurumları, arkadaşlık siteleri gibi işletmeler bulunmaktadır.

- Yayıncı: Bağlı kuruluş olarak da ifade edilir. Aynı zamanda tüketiciyi de içerir. Yayıncılar, reklamveren adına reklamları yayınlayan ve tüketici gerekli hareketi gerçekleştirdiğinde belirli bir komisyon alan internet siteleridir. Bu yayıncılar, fiyat karşılaştırma siteleri, alışveriş puan siteleri, hediye çeki dağıtan ve indirim yapan siteler, değerlendirme siteleri, günlük siteleri (bloglar) şeklinde sıralanmaktadır.

- Ağ: Satış ortağının aralarından seçim yapabileceği teklifleri içerir. Aynı zamanda ödemelerle de ilgilenir. Ağın temel işlevi aracılıktır. Ağlar reklamverenlerin tüketici hareketlerini takip etmelerini sağlayan izleme sistemlerini işleterek yayıncıya komisyon verilmesini sağlamaktadır. Reklamverenler 12 aydan kısa olmayacak şekilde bir ağa üye olurlar. $\mathrm{Ag}$, reklamverene performansa dayalı pazarlama aktiviteleri hakkında önerilerde bulunur. Yayıncılar reklamverenlerin listesine ulaşmak ve onların reklamlarını gönüllü yayınlamak için ağa gönüllü olarak üye olurlar. Bu sistem üzerinde ağ her iki tarafa da danışmanlık hizmeti vermektedir.

- Altyapı /İzleme Sağlayıcılar: Kampanyaları ölçmek ve denetlemek için hizmet yürüten şirketlerden, şirketleri hedefleyen ve ki- 
şiselleştirme yapan şirketlerden, reklam yönetimi yazılım geliştiricilerinden ve teknolojik altyapı sağlayıcılarından oluşmaktadır. İzleme sağlayıcıları, reklamverenlerin hizmetlerinden faydalanması için onlara sistemlerini lisanslarlar. Bu bir yazılım hizmeti olup sistemin işleyişine ilişkin sorumluluk reklamverene ait olmaktadir.

Bu iş modelindeki pazar yapısı, bağlı kuruluş yönetim ajansları, süper bağlı kuruluşlar ve uzman üçüncü taraf satıcılar dahil olmak üzere ikincil bir oyuncu kademesini garanti edecek şekilde karmaşık bir şekilde büyümüştür (Nosrati vd., 2013, s.59). Bağlı kuruluş ya da satış ortaklığ1 pazarlaması yoluyla çalışan işletmelere "amazon.com, gittigidiyor.com, hepsiburada.com, trendyol.com" gibi platformları örnek verilebilir (Libai vd., 2003, s.303; Aslan, 2019, s.37).

Bağlı kuruluş pazarlaması, reklamverenler tarafından sıklıkla gözden kaçmaktadır (Prussakov, 2007, s.16-17). Arama motorları, e-posta ve internet sitesi ilişkisi çevrimiçi perakendecilerin ilgisinin çoğunu çekerken, bağlı kuruluş pazarlaması çok daha düşük bir profile sahiptir. Yine de bağlı kuruluşlar, elektronik perakendecilerin pazarlama stratejilerinde önemli bir figür olmaya devam etmektedir (Nosrati vd., 2013, s.59).

Bağlı kuruluş pazarlaması, performans teşviklerini internet (çevrimiçi) pazarlamasında yer alan internet üzerinden çevrimiçi reklamcılığın sağladığ

Bağlı kuruluş pazarlamasında genellikle ödeme performansa dayalıdır. Örneğin, sistem, her satın alma için \% 10'luk bir reklam ücreti sunar. Standart kurallara göre, bir bağlı kuruluşun komisyon kazancı aşağıda sıralanan koşullara bağlıdır (Edelman, 2013, s.364):

- Kullanıcı bağlı kuruluşun sitesine göz atığında,

- Kullanıcı, tüccara özel olarak kodlanmış bağlı kuruluşu tıkladığinda

- Kullanıcı tüccar siteden satın alım yaptığında

Tablo 1'de bağlı kuruluş (satış ortaklı̆̆ı) pazarlamasına ilişkin literatür taraması bilgisinde bu kavrama yönelik yapılan çalışmaların yazarlarına, makale isimlerine ve yayın evleriyle birlikte yayın ve sayfa numaralarına yer verilmiştir. Bu tabloda belirtilen yayınlar bu çalışmanın da oluşumuna katkı sağlayan literatüre ilişkin bilgiden oluşmaktadır. 
Tablo 1. Bağlı Kuruluş (Satış Ortaklı̆̆ı) Pazarlamasına İlişkin Literatür Taraması

\begin{tabular}{|c|c|c|c|c|}
\hline Yazar Adı & Makale/Kitap Adı & Tarih & Yayınlandığı Dergi/ Kitap & $\begin{array}{l}\text { Yayın No/ } \\
\text { Sayfa }\end{array}$ \\
\hline Gedik, Y. & $\begin{array}{l}\text { Pazarlamada Yeni Bir Pencere: } \\
\text { Dijital Pazarlama }\end{array}$ & $2020 a$ & $\begin{array}{l}\text { Journal of Business in the Digital } \\
\text { Age }\end{array}$ & $\begin{array}{l}3(1) \\
63-75\end{array}$ \\
\hline Gedik, Y. & $\begin{array}{l}\text { Bağlı Kuruluş Pazarlaması: } \\
\text { Kavramsal Bir Çerçeve }\end{array}$ & $2020 b$ & $\begin{array}{l}\text { Yorum-Yönetim-Yöntem Ulusla- } \\
\text { rarası Yönetim- Ekonomi ve } \\
\text { Felsefe Dergisi }\end{array}$ & $\begin{array}{l}8(2) \\
95-110\end{array}$ \\
\hline $\begin{array}{l}\text { Olbrich, R., Schultz, } \\
\text { C. ve Bormann, P. }\end{array}$ & $\begin{array}{l}\text { The Effect of Social Media And } \\
\text { Advertising Activities On } \\
\text { Affiliate Marketing }\end{array}$ & 2019 & $\begin{array}{l}\text { International Journal of Internet } \\
\text { Marketing and Advertising }\end{array}$ & $\begin{array}{l}13(1) \\
47-72\end{array}$ \\
\hline $\begin{array}{l}\text { Gupta, P. ve Ag- } \\
\text { garwal, R. }\end{array}$ & $\begin{array}{l}\text { Reinventing and Styling Digital } \\
\text { Marketing through Affiliate } \\
\text { Marketing }\end{array}$ & 2019 & $\begin{array}{l}\text { International Journal of Research } \\
\text { and Analytical Reviews }\end{array}$ & $\begin{array}{l}6(1) \\
476-480\end{array}$ \\
\hline Sangwan, A. & $\begin{array}{l}\text { Affiliate Marketing: Meaning, } \\
\text { Working and Challenges }\end{array}$ & 2018 & $\begin{array}{l}\text { International Journal of Informa- } \\
\text { tion Movement }\end{array}$ & $\begin{array}{l}2(10) \\
199-203\end{array}$ \\
\hline Stokes, R. & $\begin{array}{l}\text { E-marketing: The Essential } \\
\text { Guide to Marketing in a Digital } \\
\text { World } \\
\text { Affiliate marketing: Can Online }\end{array}$ & 2018 & $\begin{array}{l}\text { Quirk e-Marketing, } \square \text { Red \& } \\
\text { Yellow }\end{array}$ & 322 \\
\hline Beleraj, B. & $\begin{array}{l}\text { News Portals Use Successfully } \\
\text { Affiliated Marketing in Alba- } \\
\text { nia? }\end{array}$ & 2018 & $\begin{array}{l}\text { European Journal of Marketing } \\
\text { and Economics }\end{array}$ & $\begin{array}{l}1(3) \\
66-75\end{array}$ \\
\hline $\begin{array}{l}\text { Mathur, A., Nara- } \\
\text { yanan, A. ve } \\
\text { Chetty, M. }\end{array}$ & $\begin{array}{l}\text { An Empirical Study of Affiliate } \\
\text { Marketing Disclosures on } \\
\text { YouTube and Pinterest }\end{array}$ & 2018 & https://arxiv.org/abs/1803.08488v2 & ${ }^{2} 1-7$ \\
\hline Norouzi, A. & $\begin{array}{l}\text { An Integrated Survey in Affilia- } \\
\text { te Marketing Network }\end{array}$ & -2017 & PressAcademia Procedia & $\begin{array}{l}42 \\
299-309\end{array}$ \\
\hline Ryan, D. & Dijital Pazarlama & 2017 & $\begin{array}{l}\text { İstanbul: Türkiye İş Bankası } \\
\text { Kültür Yayınları }\end{array}$ & $318-350$ \\
\hline $\begin{array}{l}\text { Jadhav, A. ve } \\
\text { Chandra, M.S.Y. }\end{array}$ & $\begin{array}{l}\text { Affiliate Marketing as an } \\
\text { Innovative Campaign in E- } \\
\text { Commerce: A Field of Rising } \\
\text { Opportunity }\end{array}$ & 2016 & $\begin{array}{l}\text { Galaxy: An International Multi- } \\
\text { disciplinary Research Journal }\end{array}$ & $\begin{array}{l}5(3) \\
5-18\end{array}$ \\
\hline $\begin{array}{l}\text { Edelman, B. ve } \\
\text { Brandi, W. }\end{array}$ & $\begin{array}{l}\text { Risk, Information, and } \\
\text { Incentives in Online } \\
\text { Affiliate Marketing }\end{array}$ & 2015 & $\begin{array}{l}\text { Journal of } \\
\text { Marketing Research }\end{array}$ & $\begin{array}{l}\text { LII } \\
1-12\end{array}$ \\
\hline $\begin{array}{l}\text { Schwarzl, S. ve } \\
\text { Grabowska, M. }\end{array}$ & $\begin{array}{l}\text { Online Marketing Strategies: } \\
\text { The Future Is Here }\end{array}$ & 2015 & Journal of International Studies & $\begin{array}{l}8(2) \\
187-196\end{array}$ \\
\hline $\begin{array}{l}\text { Prabhu, S. ve } \\
\text { Satpathy, T. }\end{array}$ & $\begin{array}{l}\text { Affiliate Marketing's Future in } \\
\text { India }\end{array}$ & 2015 & $\begin{array}{l}\text { Indian Journal of Science and } \\
\text { Technology }\end{array}$ & $\begin{array}{l}8(4) \\
278-282\end{array}$ \\
\hline Phan, H. G. & $\begin{array}{l}\text { A Technical Practice of Affiliate } \\
\text { Marketing }\end{array}$ & 2015 & $\begin{array}{l}\text { Yayımlanmamış Lisans Tez, } \\
\square \text { Lahti Üniversitesi, Finlandiya }\end{array}$ & $10-20$ \\
\hline $\begin{array}{l}\text { Yasmin, A., Tas- } \\
\text { neem, S. ve Fatema, } \\
\text { K. }\end{array}$ & $\begin{array}{l}\text { Effectiveness of Digital Marke- } \\
\text { ting in the Challenging Age: An } \\
\text { Emprical Study }\end{array}$ & 2015 & $\begin{array}{l}\text { International Journal of Manage- } \\
\text { ment Science and Business Ad- } \\
\text { ministration }\end{array}$ & $\begin{array}{l}1(5) \\
69-80\end{array}$ \\
\hline Jurišová, V. & $\begin{array}{l}\text { Affiliate Marketing in the } \\
\text { Context of Online Marketing }\end{array}$ & 2013 & $\begin{array}{l}\text { Review of Applied Socio- } \\
\text { Economic Research }\end{array}$ & $\begin{array}{l}5(1) \\
106-111\end{array}$ \\
\hline $\begin{array}{l}\text { Hossan, F. ve } \\
\text { Ahammad, I. }\end{array}$ & $\begin{array}{l}\text { Affiliate Marketing: The Case } \\
\text { of Online Content Providers in } \\
\text { Bangladesh }\end{array}$ & 2013 & World Journal of Social Sciences & $\begin{array}{l}3(2) \\
103-113\end{array}$ \\
\hline
\end{tabular}


İnternette ya da Çevrimiçi Pazarlamada Yeni Bir Kavram: Bağlı Kuruluş (Satış Ortaklığı)

Pazarlaması ve Türkiye Pazarından Bazı Örnekler

Venugopal, K., Das, Business Made Easy By Affilia- 2013 S. ve Nagaraju, M. te Marketing

Edelman, B.

(Editörler Vulkan, The Handbook of Market

N., Roth, A. E. ve Design

2013

Neeman, Z.

Nosrati, M.,Karimi,

R., Mohammadi, M. Internet Marketing or Modern ve Malekian, $\mathrm{K}$.

Cristian, M. ve

Elena, E.

Online Performance Through the Affiliate Marketing Affiliate Marketing Programs:

Haq, Z. U. A Study of Consumer Attitude Towards Affiliate Marketing Programs Along Indian Users

Mazurek, G. ve

Kucia, M.

Potential of Affiliate Marketing 2011

Jones, S.

Business to Business Internet Marketing

Wilbur, K. C. ve

Zhu, Y.

Click Fraud

2009

The Complete Guide to Affiliate Marketing on the Web: How to Use and Profit From Affiliate 2009 Marketing Programs.

Brown, B. C.

Benediktova, B. ve Affiliate Marketing Perspective 2008

Nevosad, L. of Content Providers

Prussakov, E. A Practical Guide to Affiliate Marketing 2007

Duffy, D. Affiliate Marketing and its Impact on E-commerce E-Pazarlama: İnternet Olanak-

Öncü, F. larıla Ürün ve Hizmetin Hedef2004 Pazarda Tanıtımı ve Satıșı

Fiore, F. ve Collins, Successful Affiliate Marketing S. for Merchants 2001

Hoffman, D. L. ve How to Acquire Customers on Novak T. P. the Web
Journal of Business Management $2(6)$

\& Social Sciences Research

Oxford University Press

International Journal of Economy,2(3)

Management and Social Sciences 56-63

“Ovidius" University Annals, 13(1)

Economic Sciences Series

880-884

International Journal of Research

Studies in Management

The 7th International Conference Management of Technological 1-5

Changes - MTC 2011

Florida: Maximum Press

Marketing Science

Florida: Atlantic Publisihing

Yayımlanmamış Yüksek Lisans Tezi

AM Navigator LLC

Journal of Consumer Marketing

Istanbul: Literatür Yayıncılık

Indiana: Que

Harvard Business Review

\section{Bağlı Kuruluş (Satış Ortaklığı) Pazarlamasının Hedefleri}

Bağlı kuruluş ya da satış ortaklığı pazarlamasıyla işletmelerin gerçekleştirmek istedikleri hedefler bu bölümde başlıklar halinde ele alınmaktadir.

- Gelir Hedefi: Çevrimiçi bir ortaklık programında reklamverene ait internet sitesi, bağlı kuruluşlarına internet trafiğine ve ilgili po- 
tansiyel müşteri ve satış temeline dayalı gelir sunar (Haq, 2012, s.128). Bağlı kuruluş (satış ortaklığı) pazarlama yönteminde işletmelerin nihai hedefi inovatif pazarlama kampanyalarından gelir elde etmektir. Pazarlamacılar, hizmetlerine değer katmak için odaklanmaları gereken kısa ve uzun vadeli gelir hedeflerini belirlemelidir. Bağlı kuruluş (satış ortaklığı) bir ziyaretçi reklama tıkladığında satışla sonuçlanabilecek gelir elde edebilir (Jadhav ve Chandra, 2016, s.6).

- Maliyet ve Kârlılık Hedefi: İnternet pazarlamasında üretim maliyetlerinin olmaması ve bir işletme için fiziki bir yer veya çalışan zorunluluğunun bulunmaması sonucunda ucuz ve masrafsız bir yöntemdir (Cristian ve Elena, 2013, s.882). Gelir paylaşımı modelinde, reklamın fiyatı, pazar tarafından istenen tepkinin bir fonksiyonudur. Fiyat, ölçülebilir pazar ortamında, birim satışları, yazılım indirme oranı, nitelikli olası satışlar, ürün sorguları gibi temel pazarlama hedeflerini içerir (Hoffman ve Novak, 2000, s.6). Bağlı kuruluş (satış ortaklığı) pazarlama şirketleri, genel gider veya işçilik maliyetlerini azaltmak için hedeflerini belirlerler. $\mathrm{Bu}$, pazarlamacıların gelirlerini artırma avantajından yararlanmalarına yardımcı olur. Maliyetleri azaltabilecekleri ve kârlılık hedeflerini karşllayabilecekleri internet sitelerini kendi başlarına tasarlayabilecekleri ve geliştirebilecekleri doğru internet sitesi barındırıcısını seçmeye odaklanırlar (Jadhav ve Chandra, 2016, s.7).

- Trafik Oluşturma Hedefi: Bağlı kuruluş (satış ortaklığı) pazarlamacılarının temel amacı internet trafiğini artırmaktır. İnternet sitesi analizi yapan araçlar sayesinde, pazarlamacılar internet sitesinin her gün kaç ziyaretçi tarafından ziyaret edildiğini takip edebilirler. Bir sonraki hedef, ziyaretçinin yerini bulmaktır. Dolayısıyla, tüm bu veriler pazarlamacıların değeri hizmetleriyle ilişkilendirmesine yardımcı olacaktır, burada amaç ziyaretçileri doğru bir şekilde yönlendirmek ve müşterilere uygun hizmeti sağlamaktır, bu da daha yüksek gelir sağlar (Jadhav ve Chandra, 2016, s.7). Diğer yandan, bağlı kuruluş ağlarında tüccarlar trafik izleme hizmetlerinden, raporlardan, ödeme işlemlerinden yararlanabilir ve büyük bir bağlı kuruluş veritabanına erişebilirler (Cristian ve Elena, 2013, s.881). 
- Üretkenlik Hedefi: Girişimcilerin veya bağlı kuruluş (satış ortaklı̆̆ı) pazarlamacılarının üretkenlik hedeflerini belirlemeleri, bağlı kuruluş (satış ortaklığı) pazarlamasının ilk aşamalarında satış olması ve bu nedenle ziyaretçileri belirleyip internet sitesine getirmeleri gerektiği için çok önemlidir (Jadhav ve Chandra, 2016, s.7).

- Bağlı Kuruluş (Satış Ortaklığı) Pazarlamasında Komisyon Modelleri

- Bağlı kuruluş ya da satış ortaklığı pazarlamasında yer alan ödeme ve kazanç yöntemleri şekildedir:

- İşlem Başına Maliyet (Cost Per Action - CPA): Performansa dayalı satışlarda işlem başına yapılan ödemeleri ifade eder (Stokes, 2018, s.322; Schwarzl ve Grabowska, 2015, s.193).

- Tıklama Başına Ödeme (Pay Per Click - PPC): Ürün satıcısının linkine tıklama başına yapılan ödemeleri ifade eder. Bir müşteri, satış ortağının internet sitesinde sağlanan bağlantıya veya başlığa tıklarsa ve tüccarın bir ürününü satın alırsa, karşılığında bağlı kuruluş belirli bir komisyon alır (Hossan ve Ahammad, 2013, s.107; Gupta ve Aggarwal, 2019, s.478).

- Olası Satış Başına Ödeme (Pay Per Lead - PPL): Yönlendirme başına yapılan ödemeleri ifade eder. Burada bağlı kuruluş, iletişim bilgileriyle (e-posta adresi gibi) internet tabanlı bir formu dolduran her kişi için bir komisyon alır (Schwarzl ve Grabowska, 2015, s.193; Phan, 2015, s.24).

- Gelir Paylaşımı (Pay Per Sale - PPS): Yönlendirme sonucu elde edilen kârın belirli bölümünün ödenmesini ifade eder. Komisyon ödemeleri, satılan ürün veya hizmetin fiyatına da bağlı olabilir. (Stokes, 2018, s.322; Aslan, 2019, s.37)

\section{Bağlı Kuruluş (Satış Ortaklığı) Pazarlama Çeşitleri:}

- Bağlı kuruluş ya da satış ortaklığı pazarlamasının çeşitleri Gupta ve Aggarwal'ın (2019) yapmış oldukları çalışma temelinde incelenmiş ve literatürdeki diğer yayınlarla birlikte anlatılmıştır.

- Ödül Siteleri: Özellikle az sayıda müşterisi olan işletmelerin marka görünürlüğünü artırmak için iyi bir yöntemdir. Bir reklamdan ka- 
zandıkları bir ödül olarak üyelerine komisyon ödeyerek satışları arttırırlar, ancak iptal edilen veya iade edilen satın alımlar durumunda komisyon ödemekten kaçınabilmeleri için bazı stratejilere sahip olmaları gerekir (Beleraj, 2018, s.67; Sangwan, 2018, s.201).

- Yeniden Hedefleme Satış Ortaklığı: Bu yöntem, etiketler aracilığıyla yapılır. Satın alma işlemini tamamlamamış veya bir internet sitesinden çıkmak üzere olan müşteriler için kullanılır. Yeniden hedefleme iştirakleri, bu müşterileri internet sitesinde kalmaya, satışa sunulan ürün ya da hizmeti keşfetmeye ve sipariş vermesi için inandırmaya çalışır. Bu yöntemle bu tarzdaki müşterilerin internet sitesine geri dönmeleri ve ürünü satın almaları kolaylaştırılır (Gupta ve Aggarwal, 2019, s.478; Gedik, 2020b, s.103-104).

- Kupon ve Fırsat Siteleri: Bu siteler, müşterilerine bazı belirli satın alımlarda özel çevrimiçi kuponlar (indirim kodu) sunarak satış cirosunu artırmaya yardımcı olur. Müşteri ilgili internet sitelerindeki reklama tıklayarak kuponun sağladığı faydaları deneyimleyebilir. Bu kuponlar müşterilerin gelecekteki satın alımlarında kullanılabilir. Bu tür teklifler, müşteriler tarafından hızlı bir şekilde harekete geçmek için sınırlı bir süre için sağlanmalıdır. İndirim kuponlarına yönelik aktiviteler son zamanlarda sosyal medya üzerinden bağlı ortaklık yoluyla anlaşma sağlayan etkileyicilerin (influencer) oldukça sık kullandıkları bir yöntem olarak görülmektedir (Gupta ve Aggarwal, 2019, s.478; Phan, 2015, s.18).

- İçerik Siteleri ve Günlükler (Blog): Bu tür siteler, özel ilgi alanı ve ürünün benzersiz içeriğiyle öne çıkmaktadır. Ürün inceleme siteleri, çevrimiçi forumlar ve günlükler (bloglar) bazı örneklerdir. Bu içerik siteleri yeni bir müşteri havuzu sağlar. Yeni içerik veya özel bir teklif, içerik siteleriyle etkinliğe girmenin ve bunları optimize etmenin yollarıdır (Gupta ve Aggarwal, 2019, s.478; Beleraj, 2018, s.67).

- Sosyal Ağlar ve Etkileyicilerin (Influencer) Etkisi: Bu tarzdaki bir bağlı kuruluş, sosyal ağlarda veya sponsorlu tweetlerde yüksek düzeyde hedeflenmiş gönderiler aracılı̆̆ıyla çalışır. Bu şekilde, farkındalığı artırmaya ve ihtiyaç oluşturmaya yardımcı olabilir. Bu yöntemde, güçlü bir harekete geçirme ifadesiyle, reklam öğesinin alakalı olmasını sağlamak önemli bir detaydır (Gupta ve Ag- 
garwal, 2019, s.478). Sosyal medyanın yükselişiyle birlikte etkileyiciler son zamanlarda pazarda önemli bir itici güce sahip oldular. Bu kişilerin özelliği takipçilerine doğrudan ve kişisel ulaşım sağlamasıdır. Bu durum markaların ürün ya da hizmetlerini satmak için güven açısından istenen bir ortam haline dönüşmüştür (Maile, 2018, s.11). Etkileyici ile potansiyel bir işbirliği hakkında iletişime geçme durumunda Instagram uygulamasında doğrudan mesaj (DM) yöntem olarak kullanılabilir. Mesaj, kısa, samimi ve onlarla işbirliği yapma isteği konusunda doğrudan olmalıdır (Delkamp, 2018, s.24).

- Kıyaslama Siteleri: İşletmeler dijital pazar ortamında ürün ya da hizmetlerini satmak isterken birçok tüketici açısından sayısız internet sitesini incelemek ve kıyaslamak yerine bu tür ortamlar sayesinde sunulan avantajla hızla bilgi araştırabilmektedir (Yasmin vd., 2014, s.74; Sangwan, 2018, s.201). Sigorta hizmeti satın almada ya da bir tv gibi yüksek değerli bir ürün satın almada bu internet siteleri, karşılaştırma yapıları nedeniyle satış hacminin artmasına yardımcı olur. Ürünü yalnızca ürün kalitesi temelinde değil, aynı zamanda tıklama başına kazanç temelinde de sıralarlar. Bu yöntemle çalışan hizmet işletmelerinin tanıtımı için instagram son dönemde kullanılan bir mecra olarak kendini göstermektedir. İnstagram üzerinden restoranların menüleri ve müşterilerin yaptıkları harcamalar paylaşılarak restoran seçimine yönelik bir fikir oluşumu sağlanmaktadır. (Gupta ve Aggarwal, 2019, s.478). Aynı yöntem market alışverişi için de kullanılmaktadır. Görsel 1'de bu tür faaliyetler yürüten bir internet sitesine yer verilmektedir. Bu site aynı zamanda Android ve Ios işletim sistemleriyle uyumlu olan bir uygulamaya da sahiptir. 


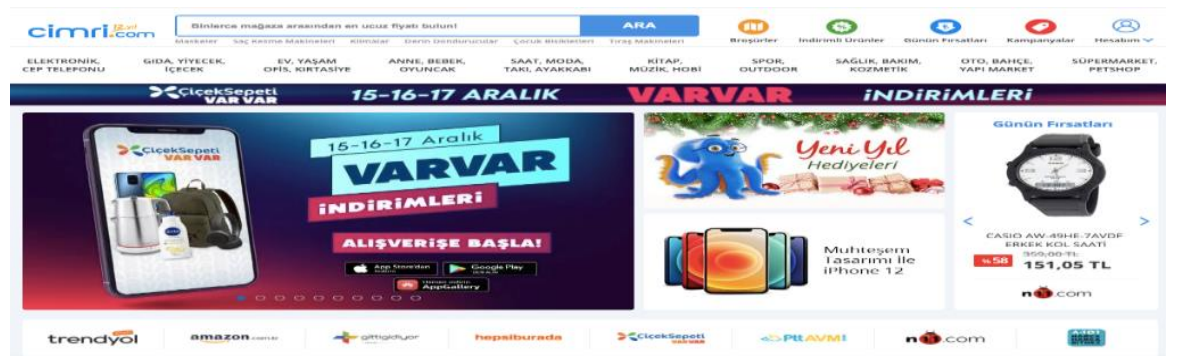

Görsel 1. Bă̆lı Kuruluş (Satış Ortaklı̆̆ı) Pazarlama Yöntemi Çeşitlerinden Kıyaslama Siteleri Örneği

\section{Bağlı Kuruluş (Satış Ortaklığı) Pazarlamasının Teknik Çalışma Yön- temi}

Bağlı kuruluşlar, izleme bağlantılarını bağlı kuruluşların internet sitelerindeki metin bağlantılarının ve afişlerin hemen arkasında bulunan bir bağlı kuruluş ağı aracılığıyla alacaklardır. Bir müşteri bu bağlantıya tıkladığında, tıklama Bağlı Kuruluş Ağı tarafından kaydedilir ve bilgisayara bir çerez bırakılır. Müşteri bir satın alma işlemini bitirir bitirmez, bağlı kuruluş ağının izleme etiketi tetiklenir. Etiketin rolü, ilgili çerezi kontrol etmektir ve müşteri bağlı kuruluş ağının yayıncısından ise satış, satış ortağı ağı tarafından kaydedilecektir. Artık hem bağlı kuruluş hem de reklamveren, satışın izlendiğini bilmelidir. Bu aşamadan sonra komisyon ödüllendirilebilir (Gupta ve Aggarwal, 2019, s.477).

Gupta ve Aggarwal'in (2019), Ivkovic ve Milanov'un (2010) ve Norouzi'nin (2017) çalışmalarında bağlı ortaklık sisteminin işleyişi anlatılmıştır. Bu aşamalar aşağıda ifade edilmekte olup bu anlatımdan yola çıkılarak bir modelleme yapılmaya çalışılmıştır. Şekil 1'de bağlı kuruluş (satış ortaklığı) pazarlama yönteminin teknik bilgisi yer almaktadır. 

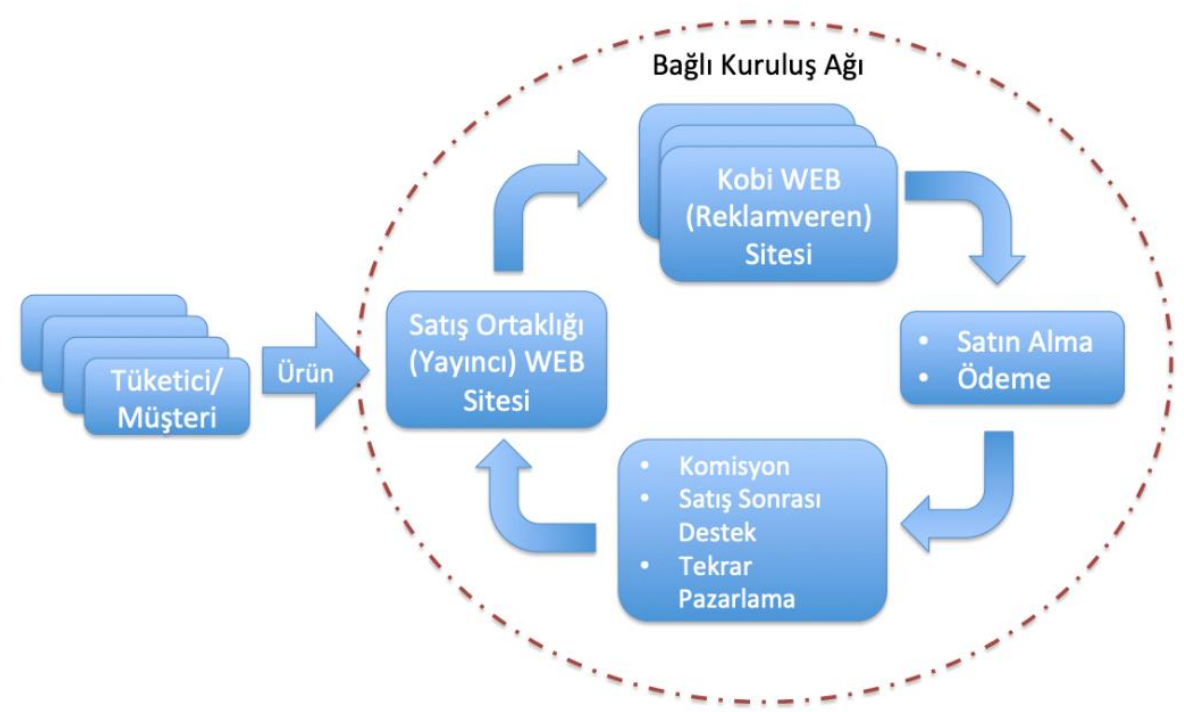

Şekil 1. Bă̆lı Kuruluş (Satış Ortaklı̆̆ı) Pazarlaması Teknik Çalışma Yöntemi

Kaynak: Gupta, P. ve Aggarwal, R. (2019). Reinventing and Styling Digital Marketing through Affiliate Marketing. International Journal of Research and Analytical Reviews, 6(1), s.477; Norouzi, A. (2017). An Integrated Survey in Affiliate Marketing Network. PressAcademia Procedia, 42, s.301 ile Ivkovic, M. ve Milanov, D. (2010) Affiliate Internet Marketing: Concept and Application Analysis, 2010 International Conference on Education and Management Technology (ICEMT 2010) s.320'den uyarlanmıştır.

1. Tüketici/ müşteri yayıncının internet sitesini ziyaret eder.

2. Yayıncının internet sitesinde, müşteri çeşitli reklam afişlerini /bağlantıları görür ve müşteri bağlı kuruluş izleme bağlantısını tıklar.

3. Bağlı kuruluş ağı bu tıklamayı izler. Bir bağlı kuruluş ağı tarafından yönlendirildiği için müşteriyi tanımlamak amacıyla müşterinin cihazına bir çerez yerleştirilir.

4. Müşteri, çevrimiçi satın alma işlemini tamamlar.

5. Reklamveren, ağda mevcut bir çerez olduğu için, satış ortağına satışı bildiren Satış Ortaklığı Ağının izleme etiketini tetikler.

6. Reklamveren, satış ortağı ağının satışla ilgili kendisine rapor vermesinden sonra, satış için bağlı kuruluş ağına önceden anlaşılan komisyon bedeli üzerinden ödeme yapar. 
7. Sürecin sonunda, bağlı kuruluş ağı komisyonu yayıncıya ödül olarak ödemeyi yapar.

\section{Bağlı Kuruluş (Satış Ortaklığı) Pazarlamasının Sunduğu Faydalar}

Başarılı bir bağlı kuruluş (satış ortaklığı) reklamveren ortaklığının anahtarı bağlı kuruluş pazarlama ilişkisinin her iki taraf için de olumlu bir sonuca sahip olmasıdır. Bağlı kuruluş pazarlaması doğası gereği ilgili her iki taraf için de kazan-kazan durumunun yer aldığı bir potansiyeli ifade eder. Bu karşılıklı kazanç durumunun içerisinde reklamverenler komisyon sistemi içerisindeki satış gücü ile öngörülebilir pazarlama maliyetinin faydalarını fark ederken, bağlı kuruluş da envanter ve altyapıya yatırım yapmadan bir gelir akışı oluşturabileceğini görür (Duffy, 2005, s.163).

Bağlı kuruluş (satış ortaklığı) iş modelinde küçük ve büyük ölçekli işletmeler (KOBİ) internet varlıklarını önemserler. Bu bağlamda internet ortamı, daha fazla ziyaretçiyi veya potansiyel müşteriyi internet sitelerine çekebilecekleri çeşitli fırsatlar oluşturur. Bu nedenle bağlı kuruluş (satış ortaklığı) şirketleri, internetin bir dünya pazarı olarak kabul edildiği küresel bir ortamda işlerini büyütmeye teşvik eder (Jadhav ve Chandra, 2016, s.6).

Reklamveren internet pazarında kullanılan ve ücretli bir reklam çeşidi olan görüntülü reklamları kullandıklarında kaç kişinin reklamı izleyeceği konusunda çekimser kalacaktır. Ancak, bağlı kuruluş pazarlaması ya da satış ortaklığ1 pazarlamasında reklamcılar boşa giden harcamaların önüne geçebilmektedirler (Wilbur ve Zhu, 2009, s.296-301).

\section{Bağlı Kuruluş (Satış Ortaklığı) Pazarlamasının Sunduğu Zorluklar}

Sponsorların beklentileri ile internet sitesi sahiplerinin beklentileri arasındaki boşluğu doldurarak geniş bir internet tanıtım araçları yelpazesi sunmaktadır. Bağlı kuruluş pazarlaması, yenilikçi bir e-promosyon aracı olarak algılanamaz. Bağlı kuruluş pazarlamasında yeni olarak görülen kavram, e-promosyon kampanyalarında bir komisyon modelinin ortak 
uygulamasıdır, çünkü çevrimiçi bu tür faaliyetlerin çoğu komisyona dayalı değildir ve sponsorlar tarafından kapsamlı internet promosyon kullanımının ana dezavantajı olarak algılanabilir (Mazurek ve Kucia, 2011, s.2).

$\mathrm{Bu}$ iş modelinin bazı zorluklarından bahsedilecek olunursa; birçok reklamveren, makul bir ücret karşılığında, istenen miktarlarda yeni müşteriler sunan güvenilir bağlı kuruluşlar bulmakta zorlanır. Teşviklerin uyumlu hale getirilmesi sözünün verilmiş olmasına rağmen, kötü ortaklar, iz sürme konusundaki eksikliklerden yararlanarak haklı olarak kazanmadıkları komisyonları talep edebilirler (Edelman ve Brandi, 2015, s.1).

Bunların dişında karşılaşılan zorluklar haksız iddiaya yol açan ve aynı zamanda insanları şikayet eden yanlış ve yanıltıcı reklam türlerine ilişkin hesaplardır. Bu tür işlerde yer alan gölgeli ve yasa dışı uygulamalar arasında yanlış reklam, ticari adların, logoların veya diğer markaların yasadışı kullanımı, istenmeyen (spam) mesaj ya da e-posta gönderme ve korsanlık yer alır. Tüccarlar bazen bağlı kuruluşlara haber vermeden ve komisyon ödemeden programları kasıtlı olarak kapatır. İştirakler bazen komisyon almak için yanlış reklam yapar ve müşteriyi yanıltır. Bu olduğunda, satıcı genellikle şikayetlerden yakınır ve potansiyel müşteriyi kaybederler. Bağlı kuruluş reklamları sonuçlar üzerinden ödeme yaptığından, içerik sağlayıcıların para kazanacaklarına dair herhangi bir garanti yoktur (Hossan ve Ahammad, 2013, s.107).

İnternet sitesi uygun şekilde tasarlanmamışsa ve reklamda kullanılan içerik daha fazlaysa, internet sayfasını açmak daha fazla zaman alır ve bu nedenle son kullanıcıların yani müşterilerin ve potansiyel müşterilerin rakiplerin internet sitelerine geçebileceğine dair bir tehdit ortaya ç1kar (Jadhav ve Chandra, 2016, s.5).

\section{Bağlı Kuruluş (Satış Ortaklığı) Pazarlamasında Başarılı Olmak İçin Gereken Adımlar}

Bu bölümde bağlı kuruluş (satış ortaklığı) pazarlamasında başarılı olmak için gereken adımlar başlıklar halinde özetlenmektedir.

- Hedef Kitleyi Tanımak: Bağlı kuruluş (satış ortaklığı) pazarlamasında başarılı olabilmek için öncelikli hedef kitleyi, onun ihtiyaçlarını 
ve beklentilerini tanımaktır. Aynı zamanda tüketicilerin ilgili internet sitelerinde ne aradıkları da profil tanımlaması açısından önemlidir (Fiore ve Collins, 2001, s.23-24)

- Güvenilir Olmak: Burada sistemde yer alan işletmelerin, ürün ya da hizmetlerini satacakları işletmelerin ürünleriyle ilgili sorgusuz güvenmek yerine referans istemeleri, bu işletmeleri araştırmaları önemlidir (Venugopal vd., 2013, s.54). Pazarlamacılar tüketicilerin rahatsız olabilecekleri ve internet sitesinden çıkabilecekleri çok fazla reklam vermemelidir. Bu nedenle, potansiyel müşterilerde bir güven oluşturmalı, ihtiyaçları anlaşılarak onlara uygun satış ortaklığı ürünü sağlanmalıdır. Bu sağlandığında, potansiyel müşterilerde kazanılan güven sonucunda olumlu yönde ağızdan ağza pazarlama aktifleşmiş olur, müşteriler ürün ya da hizmetleri başkalarını tavsiye edebilir (Jadhav ve Chandra, 2016, s.7).

- Yardımcı Olmak: Bağlı kuruluş (satış ortaklığı) reklamları bilgilendirici olmalıdır. Bu nedenle, internet sitesinde yayınlanan içerik, potansiyel müşteriler için daha yararlı ve faydalı olmalıdır. Bağlı kuruluş (satış ortaklığı) reklamları, doğru yönlendirme sağlamalı ve satış ortağı bağlantısında sağlanan içeriğin ilişkilendirilmiş değeri olması gereken potansiyel müşterilere rehberlik etmelidir (Jadhav ve Chandra, 2016, s.8; Sangwan, 2018, s.202).

- Yüksek Sorumluluk Farkındalı̆̆ı ve Şeffaflık: Dijital pazarlamayla tüketiciler işletmelerin çeşitli faaliyetleriyle karşılaşırlar. Tüketiciler, işletmelerin internet sitelerini ziyaret ederek ürün ya da hizmet hakkında ihtiyaç duyduğu bilgiyi arar, satın alım yapar ve geribildirimde bulunur. Bu süreç içerisinde tüketicilere sunulan internet sitelerinin şeffaf, doğru bir bilgi sunması beklenmektedir (Yasmin vd., 2014, s.74). Pazarlamacılar, bağlı kuruluş bağlantısında içerik hazırlarken, bağlantıları açığa çıkarmak gerektiği için dürüst olmalıdır. Pazarlamacılar, satış ortaklarını açığa çıkarmayan bir satış ortağı bağlantısı sağlarsa, potansiyel müşteriler teknolojiden anladıkları için bu konuda bilgi sahibi olacakları ve doğrudan tedarikçiyi tercih edebilecekleri olasılık daha fazladır. Şeffaf olmak, sadık müşteri oluşturmaya yardımcı olur (Jadhav ve Chandra, 2016, s.8). 
- Doğru Ürünü Seçmek: Pazarlamacılar çok sayıda ürün veya hizmete sahip olabilir, ancak genel olarak potansiyel müşterilerin beğeneceği türde başarılı ürün veya hizmetleri sergilemeleri gerekir. Aynı zamanda ürünün düşük ya da yüksek kaliteye sahip olması arasındaki farkın da bilinmesi önemlidir (Brown, 2009, s.41). Pazarlamacıların ayrıca daha çekici ve etkili olması için yenilikçi reklamlar bulması gerekir (Jones, 2009 s.270).

- Zamansız İçerik Üretmek: Dijital pazarlama ziyaretçilere ürün ya da hizmetleriyle ilgili içeriğin paylaşımı açısından fırsat sunmaktadır. Dijital medya kullanımıyla birlikte tüketici karşılaştı̆̆ içerik hakkında bilgi sahibi olurken ayn zamanda bu bilgiyi diğerleriyle de paylaşabilmektedir (Yasmin vd., 2014, s.74). Bu sebeple, pazarlamacıların zamansız içerik üretmeleri önemlidir. Ziyaretçiler ana sayfanın veya ön sayfanın internet sitesini ziyaret ettiklerinde, iyi grafik ve bilgilerin bir kombinasyonunu bekler. Ön sayfada verilen bilgilerin güncel olmaması durumunda ziyaretçiler internet sitesini terk edecektir. Bu nedenle pazarlamacılar, içerikte gerekli değişiklikleri hızlı bir şekilde yapmalıdır. Bunu zamansız bir içerik haline getirmek için pazarlamaçlar potansiyel müşterileri çekmek için ön sayfalarında "en popüler", "en yeni" gibi ifadeleri öne çıkarabilirler. Pazarlamacılar, potansiyel müşterilerin en son trendlerini, zevklerini ve tercihlerini anlamak zorundadır. Kendilerini güncellemeleri ve yeni fırsatları keşfetmeleri önemlidir. Jadhav ve Chandra, 2016, s.8; Venugopal vd., 2013, s.53)

- Sabırlı Olmak: Bağlı kuruluş (satış ortaklığı) pazarlama yönteminde gelir elde etmek zaman alır. Bu nedenle, pazarlamacilar, ziyaretçiler için daha bilgilendirici, daha yararlı içerikle gelmek için önemli ölçüde zaman ayırdıkları için yeterince sabırlı olmalıdır (Venugopal vd., 2013, s.53). Yenilikçi bir ortaklık programı oluşturmak için, potansiyel müşterileri çekmek amacıyla canlı grafiklere sahip yenilikçi reklamlar bulmak için zamana ihtiyaçları vardir. (Jadhav ve Chandra, 2016, s.8).

- Illgili Olmak ve Sürekli Değerlendirmek: Bağlı kuruluş (satış ortaklığı) pazarlama yönteminin rekabetçi bir yapıya sahip olması neticesinde sistemde yer alan tarafların yeni teknikleri ve uygulamalar hakkında bilgi sahibi olması gerekir (Cristian ve Elena, 2013, 
s.882). Pazarlamacılar, satış ortaklığı programlarındaki en son ürün veya hizmetler hakkında güncel bilgiler sağlamalıdır. Görsel çekicilik için yenilikçi reklamlar bulmaları gerekmektedir. (Jones, 2009, s.271).

\section{Bağlı Kuruluş (Satış Ortaklığı) Pazarlamasında Türkiye Pazarından Örnekler}

Bu bölümde Türkiye pazarında yer alan bağlı kuruluş (satış ortaklığı) işletmeleri anlatılmaktadır. Bağlı kuruluş (satış ortaklığı) sistemi içerisinde önemli ilk adımlardan biri güvenilir bir bağlı kuruluş işletmesiyle çalışmaktır. Bu bağlamda, sektörde olumlu ya da olumsuz anlamda ünlenmiş işletmelerin bilgileri hızla yayılmaktadır. Bu çerçeve içerisinde güvenilirlikleriyle anılan işletmelerin araştırılmasıyla ortaya çıkan işletmeler çalışma içerisinde yer almaktadır (www.niobeweb.net, 2020; https://www.neisyapabilirim.net/satis-ortakligi-veren-siteler, 2020).

Bağlı kuruluş (satış ortaklığı) sistemi içerisinde ürün kategorisinde yer alan işletmelerin komisyon oranları yaklaşık olarak \%2 ile \%20 aralığındadır.

Reklamaciton.com; reklamveren ve yayıncı taraflarını internet sitesinin ana sayfasında ayırmaktadır. Böylelikle işletme taraf olarak kolaylıkla ilgilendiği bölümün bilgilerine erişim sağlayabilmektedir. İşletme 2007 'den bu yana sektörde yer almakta olup performansa dayalı pazarlama sisteminde çözümler sunmaktadır. İşletmenin, sektörden elde ettiği bilgi ve deneyimini aktarmak üzere reklam teknolojileri ana teması altında yayınladığı e-kitapları bulunmaktadır. 


\section{Reklamstore'un Yenilikçi}

Affiliate Pazarlama Ağl

Reklamveren, ajans ve yayıncılar için

en verimli performansa dayali dijital pazarlama platformu!

Reklamveren

\section{KAMPANYA MODELLERI}

Görsel 2. Reklamaction - Bă̆lı Kuruluş (Satış Ortaklı̆̆ı) Isşletme Örneği Kaynak: https://reklamaction.com/tr

Admitad Türkiye; dünya pazarında yer alan bir bağlı kuruluş (satış ortaklığı) işletmesidir. İlgili işletmelerin ücretsiz kaydolmasıyla birlikte bağlı kuruluş işletmelerin aradıkları çözümleri kendilerine sunmaktadır. Camper, Booking, Alibaba, Udemy bu işletmeyle çalışan bazı reklamveren işletme örnekleridir.

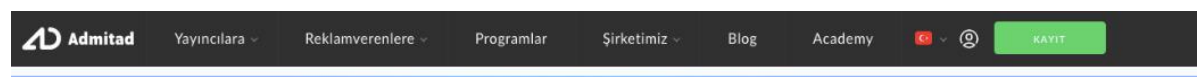

Nasıl çalışır?

Reklamverenler, sitelerine müşterileri çekmek isteyen şirketler. Onlara bunu yapmaya yardım ediniz: ürünlerini ve hizmetlerini önerip promokodlarını veya site linklerini paylașınız. Reklam başarılı olup biri linkinizden alış veriş yaparsa reklamveren size siparişin yüzdesini öder.

Görsel 3. Admitad Türkiye- Bağlı Kuruluş (Satış Ortaklı̆̆ı) İşletme Örneği Kaynak: https://www.admitad.com/tr 
Gelirortaklarl; e-ticaret alanında faaliyet yürüten işletmelere hizmet vermektedir. İşletmenin internet sitesi doğrudan iş ortaklarının kullanıcı adı ve şifreyle sisteme giriş bilgileriyle başlamaktadır.

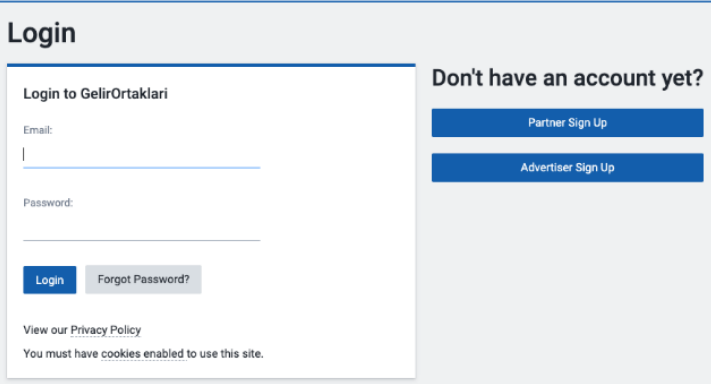

Görsel 4. Gelirortakları - Bağlı Kuruluş (Satış Ortaklı̆̆ı) İşletme Örneği Kaynak: https://panel.gelirortaklari.com/

Clickmerkez; diğer bağlı kuruluş (satış ortaklığı) işletmelerine göre farklı bir bölümlendirme uygulamaktadır. Bu bağlamda işletme, tedarikçilerden sağladığı ürünleri sattığı bir internet sitesi https://www.clicksepet.com (2020) ile satış amaçlı oluşturulan internet sitesi https://clickmerkez.com (2020) ile de hizmet vermektedir.

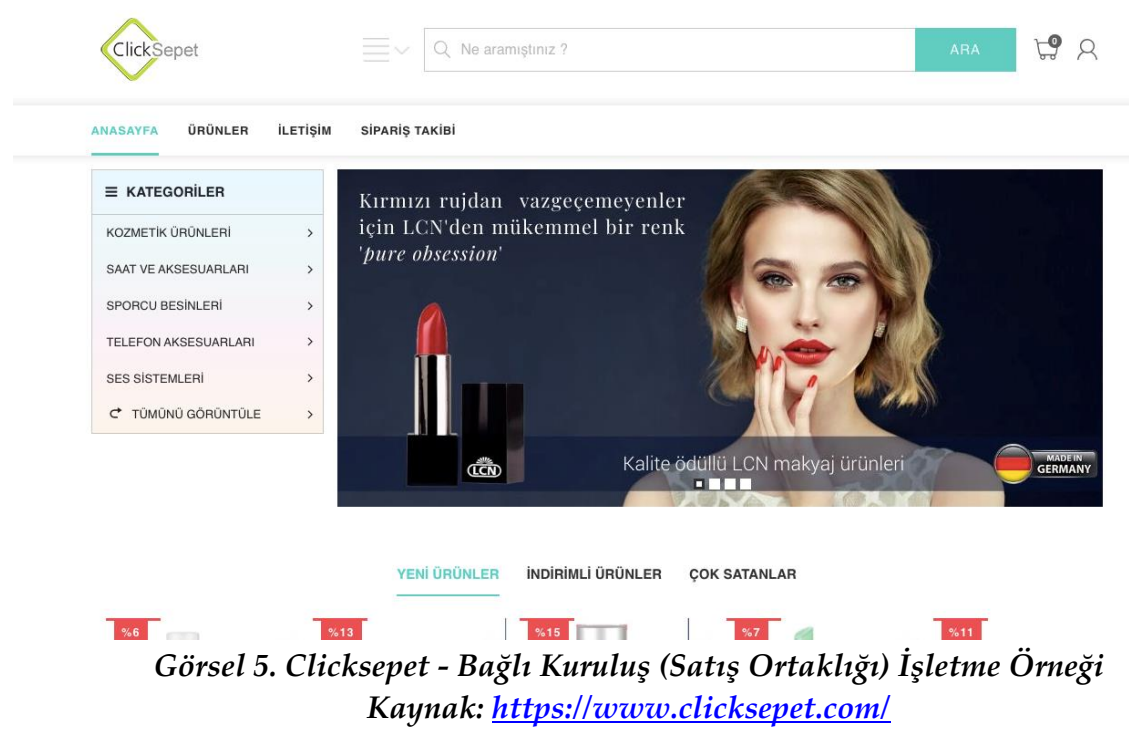




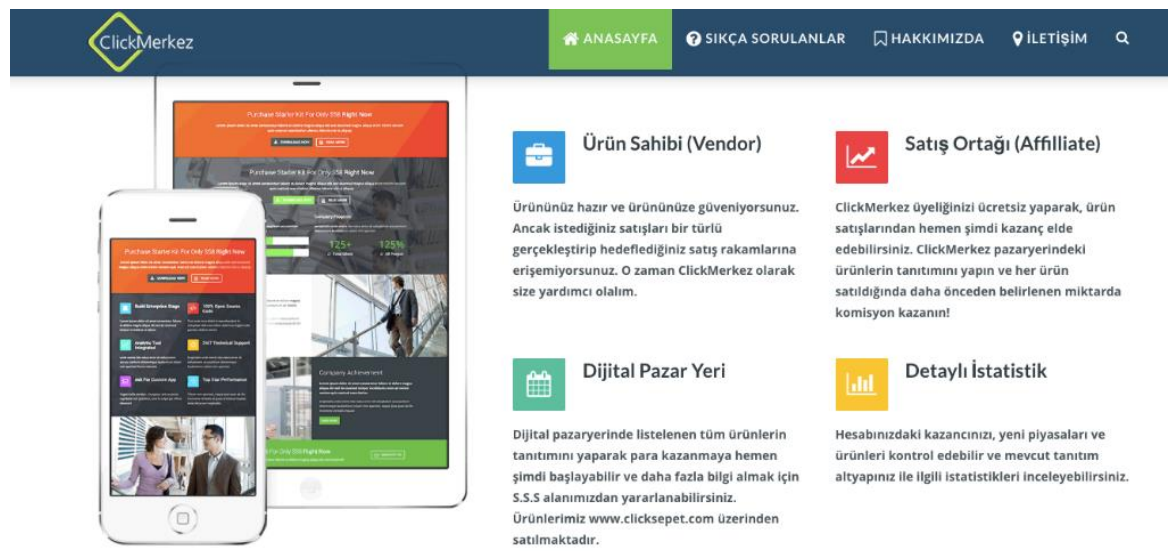

Görsel 6. Clickmerkez - Bağlı Kuruluş (Satış Ortaklığı) İşletme Örneği Kaynak: https://clickmerkez.com/

Pamukkale Turizm; yeni katıldığı bağlı kuruluş (satış ortaklığı) işletmesi modelinde sitelerinde trafik oluşturmak isteyen işletmelerin yaptığ1 satışlardan \%5 oranında komisyon sağladığ Sisteme katılmak için bir bedel ödemesi bulunmamaktadır.

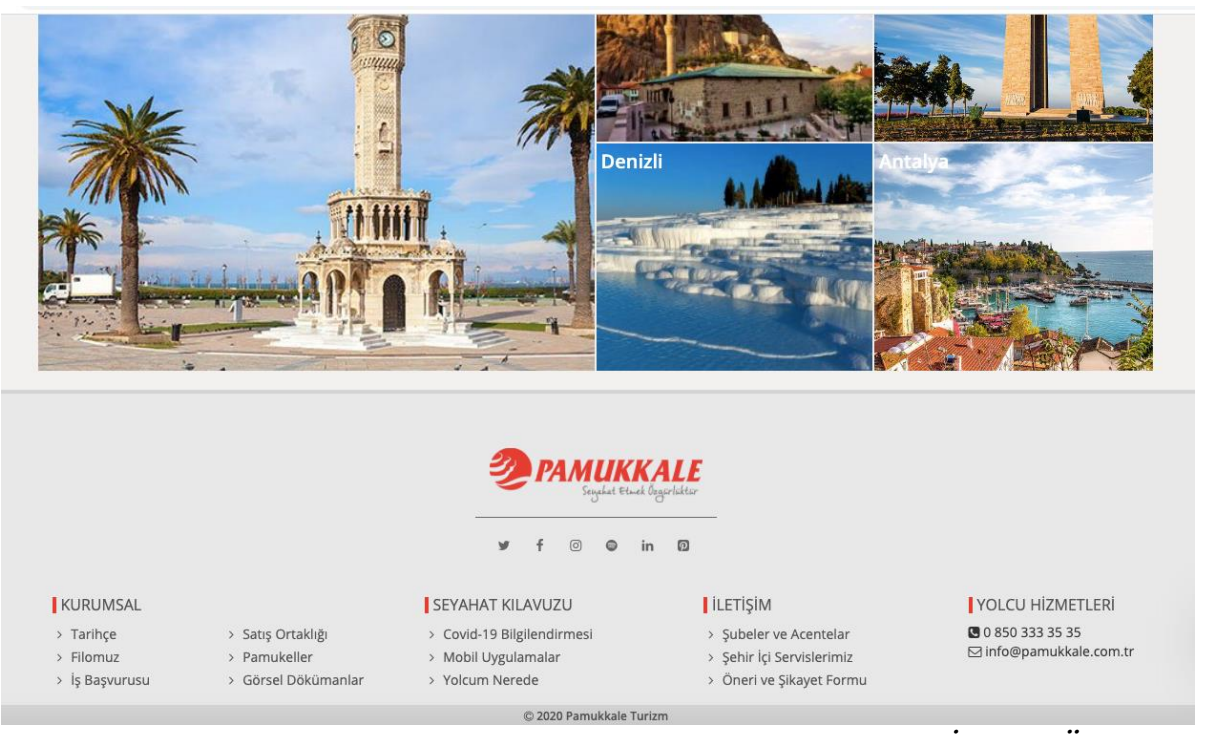

Görsel 7. Pamukkale Turizm - Bağlı Kuruluş (SatışOrtaklı̆̆l) İşletme Örneği 
Kaynak: wwww.pamukkale.com.tr

Odaklipazar; çoğunlukla çevrimiçi eğitim ve kitap satışı üzerinde odaklanmaktadır. İnternet sitesindeki "sıkça sorulan sorular" bölümünde sistemle ilgili birçok soru cevaplanmaktadır.
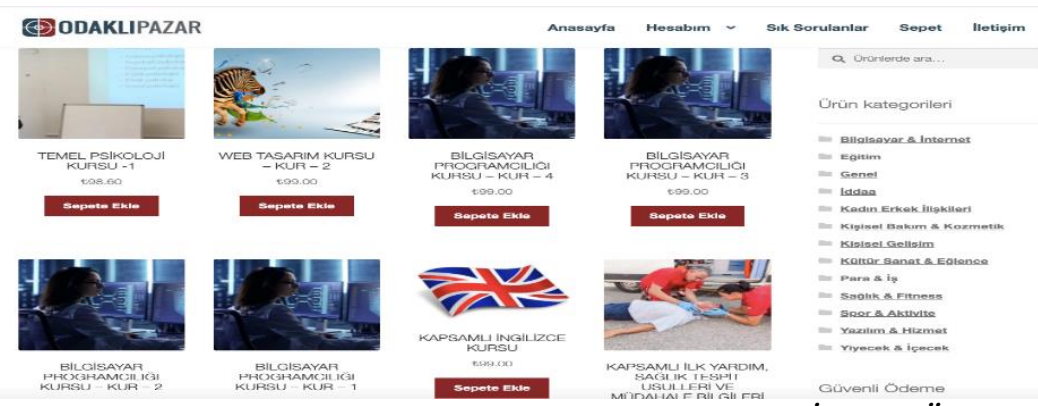

Görsel 8. Odaklıpazar - Bă̆lı Kuruluş (Satış Ortaklığı) İşletme Örneği

Kaynak: https://odaklipazar.com/tum-urunler

\section{Sonuç ve Tartışma}

Bağlı kuruluş (satış ortaklığı) pazarlaması sisteminin temel amacı satışları arttırmak olup önemli bir çevrimiçi gelir elde etme yöntemidir. Reklamverenlere, markalara ve satış ortaklı̆̆ı sağlayan pazarlamacıya gelir getiren bu yöntemde geleneksel pazarlama yöntemlerinin nispeten az kullanıldığı görülmektedir.

İnternet pazarlamasının sunduğu teknolojik çözümler ile kişisel satış değerinin birleşiminden oluşur. Bu sistem az müşterisi olan, mikro ya da küçük ölçekli ve düşük bütçeli işletmelere kâr oranlarını yükseltmek ve markalarının bilinirliğini arttırmak için fırsat sunmaktadır. Diğer yandan reklamverenin komisyon ödemesi müşterinin ilgili reklama yönelik bir harekette bulunmasıyla gerçekleşecektir. Örneğin, bir kişinin instagram hesabında karşısına çıkan "sponsorlu reklam" gibi ifadelerin yer aldığı reklama tıklaması hareketiyle reklamveren yayıncıya ödeme yapacaktır. Eğer müşteri reklamı akış sayfasında görür ve tıklamazsa reklamveren yayıncıya bir ödeme yapmak durumunda olmayacaktır. Bütçe açısından bakıldığında reklamverenler açısından düşük bütçeli ve risksiz görünen bu yöntemde müşterilerin de bilinçli davranmasının sistemin etkin ça- 
lışmasına katkısının büyük olacağı düşünülmektedir. Bu bağlamda, müşterinin ilgilenmediği bir reklama tıkladığında reklamverenin ödediği komisyon boşa gitmiş olacaktır.

Bağlı kuruluş açısından sürece bakıldığında ürün ve yer yokluğuna ek olarak mülk bağımlılığı da yoktur, mekana bağlı olmadan evden ya da istenilen yerden çalışılabilmektedir. Sistem komisyon üzerine kuruludur, çoğu zaman ücretsiz ya da bedelsiz bir üyelik sürecini içermektedir. Sistemin işlemesi için ihtiyaç olan tek şey internete bağlanmak olacaktır.

Bağlı kuruluş (satış ortaklığı) sistemi içerisinde önemli konulardan biri güvenilir bir bağlı kuruluş işletmesiyle çalışmaktır. Bu bağlamda, sektörde olumlu ya da olumsuz anlamda ünlenmiş işletmelerin bilgileri hızla yayılmakta olup aynı zamanda bu yayıncıların çalıştığı işletmelerin referans olması da önem taşımaktadır.

Reklamverenlerin zamana, pazarın özelliklerine, rekabete ve tüketicilerdeki değişime bağlı olarak pazarlama stratejilerini revize etmeleri gerekmektedir. Bu çerçevede, başarılı bir sistem algısı işleyişi içerisinde güncellemeler yaparak kendini yenileyen bir stratejiye sahip olunmasidır. Yenilenen kampanya stratejileri ile tüketicinin de ilgisi aktif olacaktir.

Reklamverenlerin sahip oldukları markanın bilinirliğinin yüksek olması ya da işletmenin büyük olması neticesinde işletmenin rehavet hatasına düşmesine sebep olabilir. Bu nedenle reklamverenlerin işletmelerinin büyüklügüne ilişkin havasına kapılmadan yenilikçi iş ve reklam modellerine karşı açık olmaları büyük önem taşımaktadır.

Rekabet ortaminda reklamverenlerin son zamanlarda en sik kullandıkları yöntemlerden biri sosyal ağlar ve etkileyiciler (influencer) üzerinden ürünlerin ya da hizmetlerin kullanımının gösterilmesi ile dikkati ve ilgiyi çekerek reklam yapmaktır. Bu yöntem geleneksel pazarlama dünyasında popüler kişilerin ya da toplumda öne çıan rol modellerin reklam ya da tanıtım faaliyetlerinde yer alması şeklindeyken dijital pazar dünyasında ise yeni medya ortamlarının kullanımıla birlikte "ünsüz" ya da "bilinirliği olmayan" hesap kullanıcılarının dijital medya ortamında kendilerinin çabalarıyla oluşan popülerlik sonucunda sahip oldukları takipçi sayılarının artışılla elde ettikleri "etkileyici" ünvanına dönüşmüştür. 
Yaşam biçimlerine göre etkileyicilerin reklamlarını yaptıkları ürün ya da hizmetlerin içerikleri değişmektedir. Örneğin, seyahat konusunda bilgi aktaran ve ulaşım ya da otel işletmelerinin reklamveren olarak yer aldıkları sistemde ilgi ve müşteri çekme eğiliminde olan bir kadın etkileyici, yaşamındaki değişimle aynı zamanda anne olma süreci ve sonrasına ilişkin sürecin de yer aldığı bir etkileyiciye dönüşebilmektedir. Bu noktada, etkileyicinin seyahat etkileyicisi ünvanına ek olarak anne olmasıyla birlikte yer alacağı yeni ortaklıklarda yeni takipçiler ve yeni müşteriler oluşacaktır. Ancak, seyahat kavramından uzaklaşma durumunda bu etkileyici seyahat odağında olan takipçilerini yani işbirliği yaptığı reklamverenlerin ürün ya da hizmetlerini takip eden müşteri ve potansiyel müşterilerini kaybedebilecektir.

Mart 2020'den bu yana Türkiye'yi ve Dünyayı etkileyen Covid 19 süreciyle birlikte pazarlama alanındaki değişim ve dönüşüm daha çok dijital pazar alanında büyümektedir. Bu bağlamda, Deloitte'un yapmış olduğu Türkiye'de Tahmini Medya ve Reklam Yatırımları 2020 İlk 6 Ay Raporu"na göre, yılın ilk dönemindeki reklamların \%55'i dijital ortamlarda gerçekleşmiştir (pazarlamasyon.com, 2020). Gelecek süre içerisinde işletmelerin dijital platformlarda sunacakları ürün ve hizmetlerin sayısında ve içeriklerinde artış olacağı ve tüketicilerin de bu büyüyen dijital pazar ortamında yer almaları aşikardır.

Bu bilgiler ışığında bağlı kuruluş (satış ortaklığı) pazarlamasına yönelik çalışmanın kavramsal bir çalışma olmasıyla birlikte son bölümde yer alan Türkiye pazarından örneklerle tüketicilere ve reklamveren konumundaki yeni kurulan ya da kurulacak işletmelere düşük bütçelerle alternatif bir pazarlama stratejisi sunmasına dikkat çekilmek istenmiştir.

Çalışmada verilen örnekler referans internet sitelerinin "güvenilir bağlı kuruluş" olarak gruplandırdıkları yayıncıları seçmiş olması çalışmanın kısıtını oluşturmaktadır. Bağlı kuruluş (satış ortaklığı) temalı iş modeli sektörde varlık göstereli 26 yılı geçmiş olsa da literatür açısından bakıldığında çalışmanın da ilgili bölümünde yer aldığı üzere son yıllarda yayın sayılarında artış görülmektedir. Türkçe yayın anlamında katkıya açık bir alan olduğu söylenebilir. Bu bağlamda bağlı kuruluş (satış ortaklığı) sisteminin işlevselliğinin satış ve marka algısı, markalaşma yönetimi gibi alanlara yönelik ölçümlenmesi sonraki çalışmaların konularını oluşturabilir. 


\title{
EXTENDED ABSTRACT
}

\section{New Concept in Online Marketing: Affiliate Marketing and Some Examples from Turkish Market}

\author{
Evrim İldem Develi \\ Istanbul Ticaret University
}

Developments and innovations in technology resulted as the presence of technology more in lives.

Technology and internet-based marketing activities such as online marketing or digital marketing have entered literature and human life. Based on these developments, businesses started to focus on media strategies created on online platforms in order to show their products or services to their target audience, to increase brand recognition, awareness and visibility and also to increase product sales.

In this context, "affiliate marketing", which is one of the concepts that emerged within the scope of performance-based marketing strategies, started to be used more often.

In first part of the study, the marketing strategy through affiliate marketing was emphasized, the parties were introduced and information was given about technical functioning and the features of the system, and also the benefits and difficulties it offers to the parties of the system.

As a method, secondary research method was used by compiling the studies in the field of marketing through affiliate marketing. Also, as a reference of some of the internet market place some reliable affiliate sources operating in Turkey are placed as affiliates example.

According to Kotler and Keller (2009, p.158), marketing communication is expressed as an environment where businesses or communities directly or indirectly inform, persuade and remind consumers about the products, brands or services they sell.

For Fill (2013, p.54-57), rapid interaction and two-way communication as an effect of technological progress require a new understanding of communication strategies and the way to connect with the target audience. The ability to interact directly is the main feature of digital media and makes it different from traditional media. 
Online advertising is a way of promotion that uses the internet to deliver marketing messages to attract customers. Having a website on the internet is no longer enough to be seen as online advertising. Instead, advertising creates the way to attract customers to that website (Hossan and Ahammad, 2013, p.106).

With the development of internet environments, various concepts have emerged in the fields of online advertising. One of these concepts i.e. affiliate marketing overlaps to some extent with other internet marketing methods, as affiliates often use organic search engine optimization (SEO), paid search engine marketing (PPC - Pay Per Click), and content marketing. Moreover, affiliates sometimes use less traditional techniques like posting reviews of products or services offered by a partner (Nosrati et al., 2013, p.59).

Affiliate marketing takes place in the literature as a type of performance-based marketing. It is described as a sort of performance-based marketing in which a business rewards one or more affiliates for each visitor or customer brought by the affiliate's own marketing efforts (Pirilancer, https://pirilancer.com/satis-ortakligi-veren-firmalar-yerliyabanci) -affiliate-marketing-sites?, 2021).

Performance-based marketing is expressed as the rewarding of the partners in return, where the customers perform an action as a result of the advertising or promotional activities carried out by one or more partners of a business for the products or services of that business. What the action or movement is predefined by the business, thus allowing the business to spend on advertising based on real and measurable results (Ryan, 2017, p.320).

Affiliate marketing is defined as an agreed system based on revenue sharing between two businesses (Mathur et al., 2018, p.1). One business rewards another business for promoting its products or services on its website. Customers access the products or services on the affiliate's website by visiting it. A fee will be paid to the publisher or the website for hosting the advertisements on the website (Prabhu and Satpathy, 2015, p.278). With this method, the retailer gains new customers. Some of the traffic will be carried over to the affiliates website. The affiliate or affiliate model is suitable for businesses that have few customers and want to 
acquire new customers (Gupta and Aggarwal, 2019, p.476; Norouzi, 2017, p.303;).

The history of affiliate marketing is known on the Prodigy network as PC Flowers \& Gifts, originally founded in 1989. Its founder, Tobin, conceived the idea of internet affiliate marketing and implemented it on his company's website. In 1998, the program had more than 2700 partners (Ryan, 2017, p.320; Wikipedia, 2020).

Second, the commission program of $\mathrm{CD}$ Now, which operates an online shopping website that sells compact disc and music-related products, dates back to 1994 . The company CD Now ran the system by bidding on various websites dedicated to writing reviews of music albums, the possibility of selling a particular album. The system worked so that the visitor could read the comments on the music server. It was creating a hyperlink to direct interested visitors to CD Now. If a purchase were made, a certain commission would be given to the server where the visitor read the review. Third and best known, Amazon Affiliate Program was developed in 1996, which is now one of the largest affiliate programs in the world (Jurišová, 2013, p.107).

In this business model, the business makes an agreement with its sales partners in the market in order to sell its product or service. In this way, the business is included in the sales partnership model. The business model can sell its product or service free of charge or in return for a certain commission fee (Öncü, 2014, p.163; Olbrich et al., 2019, p.48).

The operation in this system focuses on 4 parties (Mathur, et al., 2018, p.1-2; Öncü, 2014, p.163; Ryan, 2017, p.321-323).

Merchant / Advertiser / Brand: It is defined as the prominent product or service of the retailer or brand. Advertisers in the system include mostly retail brands, travel businesses, financial institutions, and businesses such as dating sites.

Publisher: It is referred to as an affiliate. It also includes the consumer. Publishers are websites that publish ads on behalf of the advertiser and receive a commission when the consumer takes the necessary action. These publishers are listed as price comparison sites, shopping points sites, gift vouchers and discount sites, evaluation sites, and blogs.

Network: It contains offers from which the affiliate can choose and also pay attention to payments. The main function of the network is media- 
tion. Networks operate monitoring systems that allow advertisers to track consumer movements, thereby paying commissions to the publisher. Advertisers become members of a network for no less than 12 months. The network makes recommendations to the advertiser about performance-based marketing activities. Publishers voluntarily become members of the network to access the list of advertisers and voluntarily post their ads. On this system, the network provides consultancy services to both parties.

Infrastructure / Monitoring Providers: It consists of companies that provide services to measure and control campaigns, companies that target and personalize companies, ad management software developers and technological infrastructure providers. Tracking providers license their systems to advertisers to use their services. This is a software service and the responsibility for the operation of the system belongs to the advertiser.

In affiliate marketing, payment is usually based on performance. For example, the system offers an advertising fee of $10 \%$ for each purchase. According to standard rules, an affiliate's commission earnings depend on the conditions listed below (Edelman, 2013, p.364):

- When the user browses the affiliate's site

- When the user clicks on the affiliate coded specifically for the merchant

- When the user makes a purchase from the merchant site

In Table 1, in the literature review information on affiliate marketing, the authors of the studies conducted for this concept, the names of the articles and the publication and page numbers with the publishing houses are given. The publications mentioned in this table consist of information about the literature that contributed to the formation of this study.

In this study there is an adapted scheme of affiliate marketing mechanism indicated in figure 1. And there are some examples from Turkish market which are shown and explained in picture 1 to 8 . One of the examples of affiliate marketing in Turkish market is about Pamukkale Tourism, which takes place in picture 7 . It has developed a system that provides a $5 \%$ commission from the sales made by the businesses that 
want to generate traffic on their sites in the model of the newly joined affiliate partnership. There is no fee to join the system.

As a result, this study on affiliate marketing is a conceptual study in which it is aimed to point to the reality that it offers an alternative marketing strategy with low budgets to consumers and newly established or to be established businesses in the position of advertisers, with examples from the Turkish market as in the last section. The examples given in the study are limited by the reference websites which chose publishers and grouped as "trusted affiliates". Although the business model with the theme of affiliate (affiliate partnership) has been in existence in the sector for 26 years, when we look at the literature, lately, there is increment in the number of publications. It can be said that there is an area open to contribution in terms of Turkish publication. In this context, measuring the functionality of the affiliate (affiliate partnership) system for areas such as sales and brand perception, branding management can be the subjects of future studies.

\section{Kaynakça / References}

Admitad Türkiye (2020). Bağlı kuruluş (Satış Ortaklığı) pazarlaması yapan işletme örneği. 21.12.2020 tarihinde https://www.admitad.com/tr adresinden erişildi.

Aslan, M. (2019). Şanlıurfa Ilïndeki işletmelerin e-pazarlama faaliyetlerï üzerïne bir araștırma. Yayımlanmamış Yüksek Lisans Tezi. Harran Üniversitesi, Şanlıurfa.

Beleraj, B. (2018). Affiliate marketing. Can online news portals use successfully affiliated marketing in Albania?. European Journal of Marketing and Economics, 1(3), 66-75.

Benediktova, B. ve Nevosad, L. (2008). Affiliate marketing perspective of content providers. Yayımlanmamış Yüksek Lisans Tezi. Luleå Teknoloji Üniversitesi, İsveç.

Brown, B. C. (2009). The complete guide to affiliate marketing on the web: How to use and profit from affiliate marketing programs. Florida: Atlantic Publisihing.

Cimri (2020). Bağlı kuruluş (Satış Ortaklığı) Pazarlama yöntemi çeşitlerinden kıyaslama siteleri örneği. 15 Aralı 2020 tarihinde https://wwww.cimri.com/ adresinden erişildi. 
Clicksepet (2020). Bağlı kuruluş (Satış Ortaklığı) pazarlaması yapan işletme örneği. 21.12.2020 tarihinde https://www.clicksepet.com/ adresinden erişildi.

Clickmerkez (2020). Bağlı kuruluş (Satış Ortaklığı) pazarlaması yapan işletme örneği. 21.12.2020 tarihinde https://www.clicksepet.com/ adresinden erişildi.

Cristian, M. ve Elena, E. (2013). Online performance through the affiliate marketing. "Ovidius" University Annals, Economic Sciences Series, 13(1), 880-884.

Delkamp, M. (2018). Affiliate marketing campaign with social media microinfluencers. Yayımlanmamış Lisans Tezi. Tampere Üniversitesi, Finlandiya.

Deloitte (2020). Türkiye'de tahmini medya ve reklam yatırımları 2020 ilk 6 ay raporu. 21.12.2020 tarihinde https://pazarlamasyon.com/salginsurecinde-markalar-ne-kadar-dijitallesti/ adresinden erişildi.

Duffy, D. (2005). Affiliate marketing and its impact on e-commerce. Journal of Consumer Marketing, 22(3), 161-163.

Edelman, B. ve Brandi, W. (2015). Risk, information, and incentives in online affiliate marketing. Journal of Marketing Research, LII, 1-12.

Edelman, B. (2013). The handbook of market design. Eds. Vulkan, N., Roth, A. E. ve Neeman, Z. UK:Oxford University Press.

Fill, C. (2013). Marketing communications: Brands, experiences and participation. Birleşik Krallık: Pearson.

Fiore, F. ve Collins, S. (2001). Successful affiliate marketing for merchants. Indiana: Que.

Gedik, Y. (2020a). Pazarlamada yeni bïr pencere: Dijital pazarlama. Journal of Business in the Digital Age, 3(1), 63-75.

Gedik, Y. (2020b). Bağlı kuruluş pazarlaması: Kavramsal bir çerçeve. YorumYönetim-Yöntem Uluslararası Yönetim- Ekonomi ve Felsefe Dergisi, 8(2), 95-110.

Gelirortaklari (2020). Bağlı kuruluş (Satış Ortaklığı) pazarlaması yapan işletme örneği. 21.12.2020 tarihinde https://clickmerkez.com/ adresinden erişildi.

Gupta, P. ve Aggarwal, R. (2019). Reinventing and styling digital marketing through affiliate marketing. International Journal of Research and Analytical Reviews, 6(1), 476-480. 
Haq, Z. U. (2012). Affiliate marketing programs: A study of consumer attitude towards affiliate marketing programs along Indian users. International Journal of Research Studies in Management, 1(1), 127-137.

Hoffman, D. L. ve Novak T. P. (2000). How to acquire customers on the web. Harvard Business Review, Reprint (R00305), 1-8.

Hossan, F. ve Ahammad, I. (2013). Affiliate marketing: The case of online content providers in Bangladesh. World Journal of Social Sciences, 3(2), $103-113$.

Ivkovic, M. ve Milanov, D. (2010) Affiliate internet marketing: concept and application analysis, 2010 International Conference on Education and Management Technology (ICEMT 2010), 320.

Jadhav, A. ve Chandra, M.S.Y. (2016). Affiliate marketing as an innovative campaign in e-commerce: A field of rising opportunity. Galaxy: An International Multidisciplinary Research Journal, 5(3), 5-18.

Jones, S. (2009). Business to business internet marketing. Florida: Maximum Press.

Jurišová, V. (2013). Affiliate marketing in the context of online marketing. Review of Applied Socio-Economic Research, 5(1), 106 - 111.

Kotler, P. ve Keller, K. L. (2009). Marketing management. New Jersey: Pearson Prentice Hall.

Libai, B., Biyalogorsky, E. ve Gerstner, E. (2003). Setting referral fees in affiliate marketing. Journal of Service Research, 5(4), 489-499.

Maile, F. L. (2018). Artificial intelligence and big data in affiliate marketing:A deep dive into the tools, techniques, and opportunities. Yayımlanmamış Lisans Tezi. Aalen Üniversitesi, Almanya.

Mathur, A., Narayanan, A. ve Chetty, M. (2018). An empirical study of affiliate marketing disclosures on Youtube and pinterest. 18 Aralık 2020 tarihinde https://arxiv.org/abs/1803.08488v2 adresinden erişildi.

Mazurek, G. ve Kucia, M. (2011). Potential of affiliate marketing. The 7th International Conference Management of Technological Changes - MTC 2011, 1-5.

Ne İş Yapabilirim (2020). Bağlı kuruluş (satış ortaklığı) pazarlaması yapan işletmelerin bilgi platformu. 21.12.2020 tarihinde https://www.neisyapabilirim.net/satis-ortakligi-veren-siteler adresinden erişildi. 
Niobeweb (2020) Bağlı kuruluş (satış ortaklığı) pazarlaması yapan işletmelerin bilgi platformu. 21.12.2020 tarihinde www.niobeweb.net adresinden erişildi.

Norouzi, A. (2017). An integrated survey in affiliate marketing network. Press Academia Procedia, 42, 299-309.

Nosrati, M.,Karimi, R., Mohammadi, M. ve Malekian, K. (2013). Internet marketing or modern advertising! How? Why?. International Journal of Economy, Management and Social Sciences, 2(3), 56-63.

Okalıpazar (2020). Bağlı kuruluş (satış ortaklığı) pazarlaması yapan işletme örneği. 21.12.2020 tarihinde https://odaklipazar.com/tum-urunler/ adresinden erişildi.

Olbrich, R., Schultz, C. ve Bormann, P. (2019). The effect of social media and advertising activities on affiliate marketing. Int. J. Internet Marketing and Advertising, 13(1), 47-72.

Öncü, F. (2004). E-Pazarlama: internet olanaklarryla ürün ve hizmetin hedef pazarda tanıtımı ve satışı. Istanbul: Literatür Yayıncılık.

Pamukkale Seyahat İşletmesi (2020). Bağlı kuruluş (satış ortaklı̆̆ı) pazarlaması yapan işletme örneği. 21.12.2020 tarihinde https://www.pamukkale.com.tr/bilet-satisortakligi/?refid=1\&utm source=google\&utm medium=ads\&utm campaign=satis $=$

ortakligi\&gclid=Ciw KCAiArIH BRB2EiwALfbH1HyEUhisyoHpGJ32Mi2XHtA u4pk2bw3if9suVkNoGIdGkpYm1UK1oxoCdskQAvD BwE adresinden erişildi.

PC Flowers \& Gifts (2020). Bağlı kuruluş (satış ortaklı̆̆ı) pazarlaması yapan işletme örneği. $21.12 .2020 \quad$ tarihinde https:/len.wikipedia.org/wiki/William I. Tobin\#PC Flowers and Gifts adresinden erişildi.

Phan, H. G. (2015). A technical practice of affiliate marketing. Yayımlanmamış Lisans Tez.Lahti Üniversitesi, Finlandiya.

Pirilancer (2021). https://pirilancer.com/satis-ortakligi-veren-firmalar-yerliyabanci-affiliate-marketing-siteleri adresinden erişildi.

Prabhu, S. ve Satpathy, T. (2015). Affiliate marketing's future in India. Indian Journal of Science and Technology, 8(4), 278-282. 
Prussakov, E. (2007). A practical guide to affiliate marketing. AM Navigator LLC.

Reklamaction (2020). Bağlı kuruluş (satış ortaklığı) pazarlaması yapan işletme örneği. 21.12.2020 tarihinde https://reklamaction.com/tr adresinden erişildi.

Ryan, D. (2017). Dijital pazarlama. İstanbul: Türkiye İş Bankası Kültür Yayınları.

Sangwan, A. (2018). Affiliate marketing: Meaning, Working and Challenges. International Journal of Information Movement, 2(10), 199-203.

Schwarzl, S. ve Grabowska, M. (2015). Online marketing strategies: The future is here. Journal of International Studies, 8(2), 187-196, DOI: 10.14254/2071-8330.2015/8-2/16.

Stokes, R. (2018). E-marketing: The essential guide to marketing in a digital world, quirk e-marketing.South Africa: Red \&Yellow.

Wilbur, K. C. ve Zhu, Y. (2009). Click Fraud. Marketing Science, 28(2), 293-308. Venugopal, K., Das, S. ve Nagaraju, M. (2013). Business made easy by affiliate marketing. Journal of Business Management \& Social Sciences Research, 2(6), 50-56.

Yasmin, A., Tasneem, S. ve Fatema, K. (2015). Effectiveness of digital marketing in the challenging age: An emprical study. International Journal of Management Science and Business Administration, 1(5), 69-80.

\section{Kaynakça Bilgisi / Citation Information}

İldem Develi, E. (2021). İnternette ya da çevrimiçi pazarlamada yeni bir kavram: Bağlı kuruluş (satış ortaklığı) pazarlaması ve türkiye pazarından bazı örnekler. OPUS-Uluslararası Toplum Araştırmaları Dergisi, 18(44), 8298-8332. DOI: 10.26466/opus. 913655. 